Finally, we would draw attention to the inadequacy of measurement of minute ventilation as an index of overall respiratory function in patients who are unconscious from drug overdose.

Guy's Hospital,

1 Collins, J. V., and Goulding, R., Guy's Hospital Reports, $1971,120,31$.

Bendixen, H. H., Egbert, L. D., Hedley-White, Jespiratory Care. St. Louis, Mosby, 1965.

\section{Significance of Milk pH in Newborn} Babies

SIR,-Dr. V. C. Harrison and Mr. G. Peat (2 December 1972, p. 515) reported: (1)-That breast milk has a mean pH of 7.29. (2)-That reconstituted and sterilized preparations of cow's milk had a mean $\mathrm{pH}$ of 6.51. (3)-That when the pH of such a preparation of cow's milk was raised to $7 \cdot 4$ by the addition of sodium bicarbonate its capacity to support the growth of Escherichia coli was reduced to about the same level as that of breast milk. (4)-That newborn infants fed with Similac the pH of which had been raised from 6.7 to 7.2 by the addition of either bicarbonate or trometamol gained weight more rapidly than those fed with untreated milk and had stools which were more acid and in which lactobacilli outnumbered $E$. coli. These findings suggest that merely raising the $\mathrm{pH}$ of a cow's milk feed confers on it some important virtues of breast milk. If this be true, it could be of great benefit to alter the formulation of all proprietary infant foods to provide for a $\mathrm{pH}$ of $\mathbf{7 \cdot 2}$ on reconstitution.

In the experiments on the growth of $E$. coli in milks, a $6-\mathrm{ml}$ sample was inoculated with about 200 organisms and viable counts were done at five intervals up to seven hours. After a remarkable increase in the first hour the counts rose only slowly in breast milk and cow's milk brought to $\mathrm{pH} 7.4$ and were of the order of $10,000 / \mathrm{ml}$ at the seventh hour, but the final count in cow's milk at its original pH was $66,000,000 / \mathrm{ml}$. It is quite unexpected that raising the $\mathrm{pH}$ of a slightly acid nutritive fluid to that commonly adopted for culture media should have the effect of reducing the rate of bacterial growth in it to this enormous extent.

These experiments were done with 20 samples of breast milk and 20 of "reconstituted sterile cow's milk." Whether the counts in table II and in the figure are means of all these results or those of a single representative experiment is not stated, but since the make or makes of cow's milk preparations

\begin{tabular}{|c|c|c|c|}
\hline Brand of Milk & Original pH. & $\begin{array}{c}\text { pH after adjustment } \\
\text { with } 4 \cdot 2 \% \text { sodium } \\
\text { bicarbonate. }\end{array}$ & $\begin{array}{c}\text { Counts per ml. after } \\
6 \text { hours }\end{array}$ \\
\hline $\begin{array}{l}\text { Similac } \ldots \\
\text { Cow and Gate Prepared } \\
\text { Feed } \ldots \\
\text { Trufood Prepared Feed } \\
\text { S.M.A. Prepared Feed } \\
\text { Cow and Gate Dried Milk } \\
\text { S.M.A. Dried Milk } \\
\text { Harrison and Peat's results }\end{array}$ & $\begin{array}{c}6.6 \\
6.52 \\
6.67 \\
6.54 \\
6.8 \\
6.54 \\
\text { quoted as range } 5.6-6.95\end{array}$ & $\begin{array}{l}7 \cdot 29 \\
7 \cdot 38 \\
7 \cdot 27 \\
7 \cdot 32 \\
7 \cdot 3 \\
7 \cdot 27 \\
7 \cdot 4\end{array}$ & $\begin{array}{rrr}29 \times 10^{4} & 21.8 \times 10^{4} \\
32 \cdot 8 & \times 10^{4} & 23 \times 10^{4} \\
12 \times 10^{6} & 14 \times 10^{6} \\
39 \times 10^{5} & 44 \times 10^{5} \\
86 \times 10^{5} & 79 \times 10^{5} \\
40 \times 10^{5} & 35 \times 10^{5} \\
21 \times 10^{5} & 79 \times 10^{5} \\
40 \times 10^{5} & 36 \times 10^{5} \\
60 \times 10^{5} & 57 \times 10^{5} \\
65 \times 10^{5} & 54 \times 10^{5} \\
15 \times 10^{5} & 22.4 \times 10^{5} \\
38 \times 10^{5} 13.9 \times 10^{5} \\
6 \times 10^{6} \\
1.9 \times 10^{4} \\
1.9\end{array}$ \\
\hline
\end{tabular}

tion "has a bacteriostatic effect on specific $E$. coli in vitro."-We are, etc.

W. A. Cox Senior Bacteriologist D. B. GAMMACK Chief Scientist
L. P. GARROD


Hours of incubation

Counts of $E$. coli O111/B4 in Cow and Gate dried milk during six hours of incubation at $37^{\circ} \mathrm{C}$ Harrison and Peat's results included. $\mathbf{O}=$ Harrison and Peat's results (without buffer), $\mathbf{X}=$ Cow and Gate $(\mathrm{pH}$ 68), $\Lambda=C$ with and Gate
$(\mathrm{pH} 7.3)$.

are unspecified, the experiments cannot in either case be exactly repeated. We have repeated them with dried milks in common use for infant feeding in this country, together with Similac, the preparation used in the authors' feeding tests. Their technique was followed exactly, including the use of $E$. coli $0111 / \mathrm{B} 4$ as test organism, except that experiments were terminated at six hours and that viable counts were done in pour plates of McConkey's medium, which gives more exact results than the drop method of Miles et al. (To test the reproducibility of these counts, eight separate dilutions and platings were made of a milk after six hours' incubation; average and maximum deviations from the mean were 25 and $40 \%$ respectively.)

Final counts in durplicate experiments with six milks at their original $\mathrm{pH}$ and adjusted to about $\mathrm{pH} 7 \cdot 3$ are shown in the table. In all milks growth proceeded at a closely similar rate in the two samples, graphs of the counts being almost superimposable. Those obtained in one of the milks (Cow and Gate Dried Milk) are shown in the figure, which includes the results of Dr. Harrison and Mr. Peat for comparison. None of the final counts differ significantly except those in Cow and Gate Prepared Feed, which show an approximately three-fold difference between those at pH 6.52 and at 7.38. This is the only result even faintly resembling those reported by Dr. Harrison and $\mathbf{M r}$. Peat. We therefore contest their conclusion that raising the pH of a cow's milk preparaand subervision. Because the hospital for the mentally handicapped is ideally a therapeutic community the consultant in it has generally been more involved in administrative matters than many of his colleaques. The consultants in this work have an ethos of their own: thev receive symbathetically parients whom others often appear to find it bevond their abilities and resources to helo. The consultant in mental handicas works more freourntlv at a practical level with human relationshios rather than with the avolication of rerhnoloev. He is co-ordinator of the multidisciplinary team which brings its skills to bear 